Table 1. COMPARISON OF PROTRIN DETERMINATION BY THE PHENOL REAGENT METHOD AND BY THE MEMBRANE FHLTER METHOD Amount of protein observed*

\begin{tabular}{|c|c|c|}
\hline Ingredient & By phenol reagent & By membrane filter \\
\hline Non & $20 \cdot 8 \pm 0 \cdot 2$ & $20 \cdot 0 \pm 0 \cdot 1$ \\
\hline $\begin{array}{l}\text { Tyrosine } 4 \mu \mathrm{g} \\
\text { Tris-HCl } 0.005 \text { molar }\end{array}$ & $20 \cdot 8^{+} \pm 1 \cdot 2$ & $20 \cdot 0 \pm 0 \cdot 3$ \\
\hline $\begin{array}{l}\text { Tris-HCl } 0.005 \text { molar } \\
\text { CMP } \ddagger 50 \mu \mathrm{g}\end{array}$ & $\begin{array}{l}22 \cdot 1^{+} \pm 1 \cdot 8 \\
21 \cdot 1 \pm 0 \cdot 5\end{array}$ & $\begin{array}{l}19 \cdot 9 \pm 0 \cdot 1 \\
18 \cdot 7 \pm 0 \cdot 1\end{array}$ \\
\hline
\end{tabular}

* Figures are averages of five samples. Each sample contained $20 \cdot 0 \mu \mathrm{g}$ of serum albumin.

$\uparrow$ Tyrosine and tris- $\mathrm{HCl}$ alone gave colour reaction corresponding to $15.8 \mu$ and $21.6 \mu$ of serum albumin respectively. The values shown above wore corrected for these fligures.

$\ddagger$ Cytidine monophosphate.

Tests for chemicals which usually interfere in current procedures are summarized in Table 1. The materials which irritated the ultra-violet absorption method and the chemicals which react with phenol reagent showed virtually no interference in our method of assay.

Harumi Kuno

Hirozi K. KiHARA

Department of Paediatrics, and

Department of Molecular Biology,

Keio University School of Medicine,

Tokyo.

Received February 20, 1967.

Lowry, O. H., Rosebrough, N. J., Farr, A. L., and Randall, R. J., J. Biol. Chem., 198, 265 (1951).

${ }^{2}$ Hu, A. S., Epstein, R., Halvorson, H. O., and Bock, R. M., Arch. Biochem. Biophys., 91, 210 (1960).

${ }^{3}$ Lodish, H. F., and Zinder, N. D., Biochem. Biophys. Res. Commun., 19, 269 (1965).

- Watanabe, I., Miyake, T., Sakurai, T., Shiba, T., and Ohno, T., Proc. Japan Aead., 43, 204 (1967).

\section{Inhibition of ADP Phosphorylation by the Atractyloside of Yeast Respiratory Particles}

Atractyloside is known to prevent the phosphorylation of exogenous ADP by intact liver mitochondria ${ }^{1}$, and to block the passage of adenine nucleotides across the mitochondrial membrane ${ }^{2-7}$. The question therefore arises as to whether or not these two effects of atractyloside are independent of each other.

An experimental approach to this problem could be made by using yeast respiratory particles (damaged mitochondria prepared by disruption of yeast cells); these particles, in contrast to liver mitochondria, are able to utilize for the substrate-linked phosphorylation not only $\alpha$-ketoglutarate, but also acetyl-carnitine ${ }^{8,9}$.

In contrast to liver mitochondria, it is possible to prepare a soluble extract from these particles which is able, like the particles themselves, to utilize acetyl-carnitine in the presence of succinate for ADP phosphorylations through the last steps of the substrate-linked phosphorylation.

The action of atractyloside has been tested on the particulate and the soluble systems. The results are shown in Table 1.

It can be clearly seen that the acetyl-carnitine dependent phosphorylation of ADP is strongly inhibited by atractyloside when catalysed by respiratory particles, while it is completely unaffected in the soluble enzyme system.

These results suggest that an insoluble structure is required before atractyloside can exert its inhibitory effect, and that any specific inhibition by atractyloside on the enzymes involved in the substrate level ADP phosphorylation described can be ruled out.

It is also interesting that arsenate, unlike atractyloside, prevents synthesis of ATP through substrate level phosphorylation, both in the particulate and in the soluble system.

The requirement of an insoluble structure for the inhibitory effect of atractyloside does not necessarily mean that this inhibitor acts by preventing an enzyme translocation of adenine nucleotides from outside to inside the mitochondrial membrane.
Table 1. AFFECT OF ATRACTYLOSIDE ON ATP SYNTHESIS BY YEAST RESPIRATORY PARTICLES AND BY THEIR SOLUBLE EXTRACT IN PRESENCE OF ACETYL CARNITINE

Acetate + carnitine + succinate Acetyl-carnitine + succinate

Acetyl-carnitine + succinate + atractyloside ATP (m $\mu$ moles) formed
Particles Soluble extract

Yeast particles $(1 \mathrm{ml}$., equivalent to $30 \mathrm{mg}$ of protein) were incubated in 2.7 $\mathrm{ml}$. of a medium containing $100 \mu$ moles of tris-hydrochloric acid buffer $p$ $7 \cdot 4,12 \mu$ moles of magnesium chloride, $1 \mu$ mole of phosphate, $20 \mu$ moles substrate, except succinate $(10 \mu$ moles $)$ and $30 \mu$ moles of malonate, $0 \cdot 6$ $\mu$ moles of atractyloside when present. No ADP or AMP was added. Incubation was for $10 \mathrm{~min}$ at $25^{\circ} \mathrm{C}$. Concentration of ATP at zero time was 44 $\mathrm{m} \mu$ moles. Of the reaction mixture $1.5 \mathrm{ml}$. contained $1 \mathrm{mg}$ of soluble protein, $75 \mu$ moles of tris-hydrochloric acid buffer, $p \mathbf{H} 7 \cdot 4,10 \mu$ moles of substrate, except succinate ( $5 \mu$ moles), $20 \mu$ moles of magnesium chloride, $0.4 \mu$ mole of coenzyme $A, 20 \mu$ moles of phosphate, $2 \mu$ moles of ADP, $80 \mu$ mole of potassium fluoride, $0.3 \mu$ moles of atractyloside when indicated, 100 Kunitz-MacDonald units of hexokinase, and $50 \mu$ moles of glucose. Incubation was for $10 \mathrm{~min}$ at $25^{\circ} \mathrm{C}$. The soluble extraet was prepared at $0^{\circ} \mathrm{C}$ by mechanical disruption ${ }^{8}$ of yeast particles with a Virtis homogenizer for $20 \mathrm{~min}$ at 20,000 r.p.m. in the presence of 0.2 molar potassium chloride, 0.5 molar EDTA, 50 mmolar potassium phosphate, $p \mathbf{H} 7 \cdot 4$. After centrifugation for $15 \mathrm{~min}$ at $100,000 \mathrm{~g}$, the clear supernatant $(10 \mathrm{ml}$.) was passed through a column of 'Sephadex $G-25$ ' $(1.8 \times 26 \mathrm{~cm})$ previously equilibrated with 10 mmolar phosphate, $p H \mathbf{H} 7 \cdot 5$. Proteins were determined by the biuret method

As was previously shown, an insoluble mitochondrial structural protein is able to bind adenine nucleotides in a way which is inhibited and reversed by atractyloside ${ }^{11}$.

This observation suggests that the binding of adenine nucleotides to the structural protein may be the preliminary step required for some processes involving adenine nucleotides in intact mitochondria.

We thank Miss Carla Munari for technical assistance.

V. Moret

L. A. Pinna

M. LORINI

N. Siliprandi

Institute of Biological Chemistry and

Enzymological Unit of Consiglio Nazionale delle Ricerche, University of Padova, Padova.

Received February 27; revised March 28, 1967.

${ }^{1}$ Bruni, A., in Regulation of Metabolic Processes in Mitochondria (edit. by Tager, J. M., Papa, S., Quagliariello, E., and Slater, E. C.), B.B.A. Tager, J. M., Papa, S., Quagliariello, E., and Slater, E.

${ }^{2}$ Kemp, A., and Slater, E. C., Biochim. Biophys. Acta, 92, 178 (1964).

${ }^{3}$ Moret, V., Pinna, L. A., Sperti, S., Lorini, M., and Siliprandi, N., Biochim. Biophys. Acta, 82, 603 (1964). Heldt, H. W., Jacobs, H., and Klingenberg, M., Biochem. Biophys. Res.
Commun., 18, 174 (1965).

${ }^{5}$ Chappel, J. B., and Crofts, A. R., Biochem. J., 95, 707 (1965).

- Brierley, G., and O'Brien, R. L., J. Biol. Chem.,240, 4532 (1965).

'Duee, E. D., and Vignais, P. V., Biochim. Biophys. Acta, 107, 184 (1965).

${ }^{8}$ Gregolin, C., Scalella, P., and Siliprandi, N., Boll. Soc. Ital. Biol. Sper., 40 , 1932 (1964)

- Siliprandi, N., Moret, V., Pinna, L. A., and Lorini, M., in Regulation of Quagliariello, E., and Slater, E. C.), B.B.A. Library, 7,247 (Elsevier Publishing Co., Amsterdam, 1966).

${ }^{10}$ Gornall, A. G., Bardawill. C. J., and David, M. M., J. Biol. Chem., 177, 751 $(1949)$.

${ }^{11}$ Moret, V., Lorini, M., Fotia, A., and Siliprandi, N., Biochim. Biophys. Acta, $124,433(1966)$.

\section{Translocation of DNA of Bacterial Origin in Lycopersicum esculentum by Ultracentri- fugation in Caesium Chloride Gradient}

WE have previously reported ${ }^{1,2}$ results showing that exogenous tritiated DNA molecules can migrate in the xylem of tomato plant and, after some degradation, be taken up by the meristematic cells. We now report our investigation of the nature of the radioactive molecules recovered after incubation of the plant by bacterial DNA using ultracentrifugation in a caesium chloride gradient.

We used the tomato variety 'Tuckwood' treated in the following way. Apical shoots $(5-9 \mathrm{~cm})$ of adult plants with young leaves and without roots were dipped into a solution of Escherichia coli or Bacillus subtilis tritiated DNA for $6 \mathrm{~h}$. They were then transferred to water for $48 \mathrm{~h}$. The region dipped in the DNA was removed before 